\title{
Seasonal variation of the crustacean fauna in the belowground and aboveground strata in a Halodule wrightii meadow of northeastern Brazil
}

\author{
Kcrishna V. S. Barros', Jesser F. Souza-Filho², Ricardo J. C. Paiva² Catarina L. Araújo-Silva², \\ Alexandre O. Almeida ${ }^{3}$ \& Cristina A. Rocha-Barreira ${ }^{1}$
}

\footnotetext{
1. Universidade Federal do Ceará, Instituto de Ciências do Mar, Laboratório de Zoobentos. Av. da Abolição, 3207, 60165-081, Meireles, Fortaleza, CE, Brazil. (kcrishna@gmail.com)

2. Universidade Federal de Pernambuco, Departamento de Oceanografia, Laboratório de Carcinologia. Av. Arquitetura, s/n, 50670-901, Caixa-Postal 50740-550, Cidade Universitária, Recife, PE, Brazil.

3. Universidade Federal de Pernambuco, Centro de Ciências Biológicas, Departamento de Zoologia. Av. Prof. Moraes Rego, 1235, 50670-420, Cidade Universitária

Universidade Feder
Recife, PE, Brazil.
}

Received 25 April 2017

Accepted 08 November 2017

DOI: $10.1590 / 1678-4766 e 2017048$

\begin{abstract}
The different microhabitats provided by seagrasses and the habit of the species determinate the vertical distribution of crustaceans. This study verified the influence of the seasonality on the spatial distribution of the crustacean community associated with a Halodule wrightii meadow. From April 2006 to July 2007, we performed fifteen samplings in Goiabeiras Beach, Ceará State, each with five sectioned replicates in belowground and aboveground. Cumaceans and the amphipod Hyale media (Dana, 1853) had a higher frequency, density, and dominance than the other taxa, in both strata. The community exhibited gradual changes along the study, in both the belowground and aboveground strata, but the seagrass structure was not sufficient to explain the vertical distribution of the crustacean fauna along the time.
\end{abstract}

KEYWORDS. Seagrass, shoal grass, benthic communities.

RESUMO. Variação sazonal da fauna de crustáceos nos estratos subterrâneo e aéreo em uma pradaria de Halodule wrightii do nordeste do Brasil. Os diferentes microhabitats proporcionados pelas pradarias marinhas e o habito das espécies determinam a distribuição vertical de espécies de crustáceos. Este estudo verificou a influência da sazonalidade sobre a distribuição espacial da comunidade de crustáceos associada a uma pradaria de Halodule wrightii. De abril de 2006 a julho de 2007, foram realizadas 15 amostragens na praia das Goiabeiras, estado do Ceará, em cada uma com cinco amostras seccionadas em partes aérea e subterrânea. Cumáceos e o anfípode Hyale media (Dana, 1853) tiveram a maior frequência, densidade e dominância em relação a outros táxons, em ambos os estratos. A comunidade exibiu mudanças graduais ao longo do estudo, em ambos os estratos aéreo e subterrâneo, mas a estrutura da pradaria não foi suficiente para explicar a distribuição vertical da fauna de crustáceos ao longo do tempo.

PALAVRAS-CHAVE. Pradarias marinhas, capim marinho, comunidades bentônicas.

Seagrasses are marine angiosperms that provide a tri-dimensional habitat for benthic organisms, with a canopy along the water column and a root system that penetrates the sediment (OrTh et al., 1984; Hemminga \& DuARTe, 2000; NAKAOKA, 2005; BJÖRK et al., 2008). Thus, these habitats are used in several ways, with algae and animals attached to the leaf surface (epiflora and epifauna), dispersed along the bottom (epibenthic organisms), or in the sediment (infauna) (NAKAOKA, 2005). The settlement of these organisms attracts visiting groups, especially fish shoals and large herbivores, and promotes increased productivity in the ecosystem (ZIEMAN \& ZIEMAN, 1989; NAKAOKA, 2005; BJÖRK et al., 2008).

In general, studies on the macrofauna associated with seagrasses address different groups of the benthic fauna (Corbisier, 1994; JeRnAKOFF \& NiElsen, 1998; NAKAOKA et al., 2001; Bologna \& Heck JR., 2002; Harriage et al., 2006; Rosa \& Bemvenuti, 2007; Barros \& RochaBARREIRA, 2009/2010). Few studies are still realized on specific faunal assemblages, such as molluscs (TOYOHARA et al., 1999; Alves \& AraúJo, 1999; Costa \& Ávila, 2001; CREed \& KinNuPP, 2011; BARros \& RochA-BARREIRA, 2013; BARros et al., 2013), polychaetes (BONE \& SAN MARTín, 2003; OMENA \& CREED, 2004), nematods (DA Rocha et al., 2006) and crustaceans (GARCIA et al., 1996).

Despite of the few specific surveys in seagrass meadows, crustaceans are one of the main groups of seagrass meadows, also composing most of the benthic macrofauna associated with these substrates (KIKUCHI, 1974; D'InCAO, 1982; Phillips \& MeÑez, 1988; GarCia et al., 1996; Hemminga \& DuARTe, 2000; NAKaOKA et al., 2001; NAKAOKA, 2005; HARRIAGE et al., 2006). Moreover, amphipods, copepods and shrimps are important components of the diet of fishes, including species that are commercially 
and recreationally important (Hemminga \& DUARTe, 2000).

Many species of crustaceans settle on the meadows after the larval stage and remain there until reaching the adult phase (Hemminga \& DuARTe, 2000; NAKAOKA, 2005; BJörK et al., 2008). They include a diversity of forms of organisms that can live in different habitats provided by these plants, as the sediment rich in organic matter and the surface of the stable sediment provided by the rhizome/root system, and also the leaves canopy, which can offer food and more stable environmental conditions (ABELE, 1974; ZIEMAN \& Zieman, 1989; Gambi et al., 1995; Hemminga \& Duarte, 2000; Williams \& HeCK, 2001).

Thus, the literature suggest that the different microhabitats provided by the seagrass added to the species habits are sufficient to determinate the vertical distribution of the crustacean species. The aim of this study was to observe the influence of the seasonality on the crustacean community associated with the belowground and aboveground strata of a Halodule wrightii Ascherson meadow of the semiarid coast of northeastern Brazil.

\section{MATERIAL AND METHODS}

Study Area. Goiabeiras beach $\left(03^{\circ} 41^{\prime} 31^{\prime \prime} \mathrm{S}\right.$ $38^{\circ} 34^{\prime} 49^{\prime \prime} \mathrm{W}$ ) is located to the east of the Ceará river outfall, Fortaleza, state of Ceará (Fig. 1), on the semiarid coast of northeastern Brazil.

Beach rocks cover an area of approximately 500 $\mathrm{m}$ parallel to the coast, where macroalgae banks cohabit with a small meadow of the seagrass Halodule wrightii, with a maximum width of around $30 \mathrm{~m}$. The meadow is regularly immersed during low spring tides (BARROS \& ROCHA-BARREIRA, 2014). The local climate is rainy tropical with a long dry season - Aw' (KöPPEN, 1948). The rainy season occurs between February and May, with weak winds intensifying in the dry season, between August and November (Morais et al., 2006).

Fieldwork and material processing. Fifteen monthly samplings were performed from April 2006 to July 2007, each with five random replicates, collected with the help of a core $\left(0.0078 \mathrm{~m}^{2}\right)$ buried at $10 \mathrm{~cm}$. The number of samples was determined after the elaboration of a performance curve for the macrofauna groups from a previous sampling. The subsequent samplings took into account the size of the small seagrass meadow studied here, as recommended by DUARTE \& KIRKMAN (2001), using a sampling design based on BURDICK \& KENDRICK (2001) for patched meadows. Each core was sectioned in belowground and aboveground, the former of which included a thin upper layer (smaller than $0.5 \mathrm{~cm}$ ) of the sediment.

The samples were transported to the Laboratório de Zoobentos do Instituto de Ciências do Mar, Universidade Federal do Ceará (Brazil) and washed in running water with a $0.5 \mathrm{~mm}$ sieve to retain the macrofauna. Specimens were preserved in a $70 \%$ alcohol solution, and the crustacean fauna was subsequently identified in the Laboratório de Carcinologia da Universidade Federal de Pernambuco to

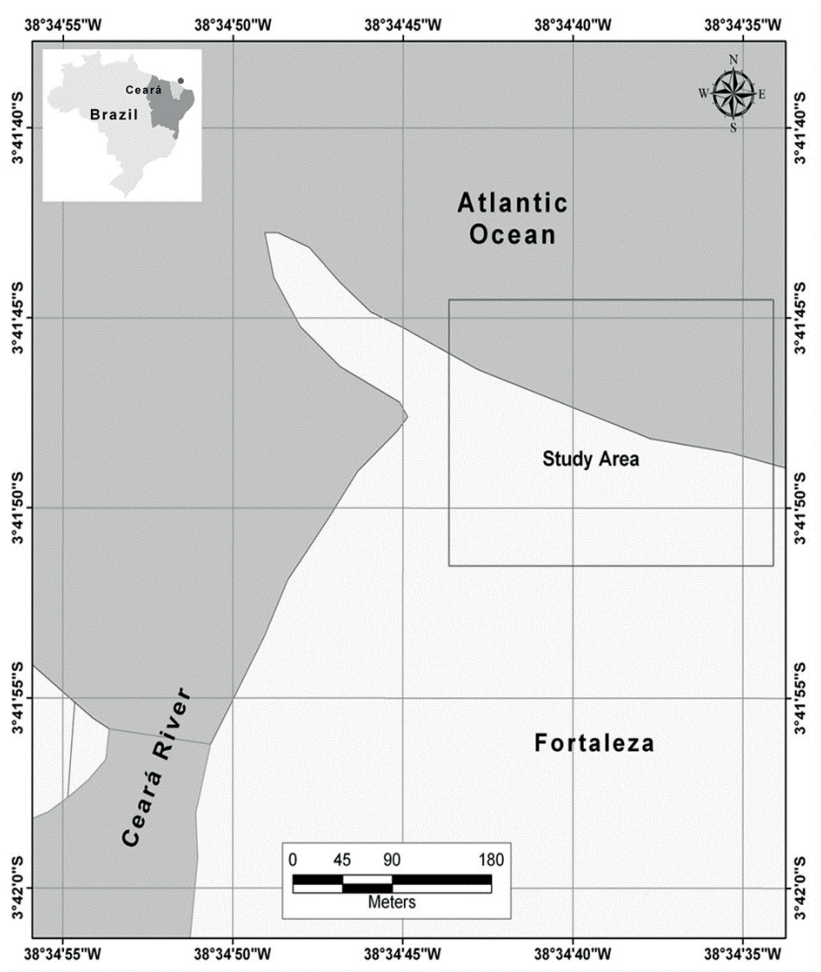

Fig. 1. Location of study area. Goiabeiras Beach, city of Fortaleza, state of Ceará, northeastern Brazil.

the lowest possible taxonomic level, excepting cumaceans and mysids, due to the lack of taxonomists.

Statistical analysis. We determined frequency of occurrence $(\mathrm{F}<10 \%$ - rare; $10 \%<\mathrm{F}<40 \%$ - few common; $40 \%<\mathrm{F}<70 \%$ - common; $\mathrm{F}>70 \%$ - more common), density (specimens per grams of dry weight of $H$. wrightii), and species dominance for the belowground and aboveground strata, in the dry and rainy seasons. We also obtained the Shannon diversity and Pielou evenness indices, which were submitted to a two-way ANOVA in order to observe the isolated and combined effects of the vertical distribution in the meadow (below/aboveground stratum), and seasonality (dry/rainy period).

Bray-Curtis analyses were performed to determine similarities among the samples of crustacean fauna in each stratum of the seagrass meadow, using the abundance of the species, previously transformed in $\log (\mathrm{x}+1)$. After obtaining the graph of similarity (Cluster), the groups of samples with more than $40 \%$ of similarity were compared using the similarity percentage (SIMPER) analysis to determine the taxa that favoured similarity among the samples. An analysis of similarity (ANOSIM) was performed to determine the significance of seasonal variations in the groups of samples in each stratum.

These analyses (diversity, evenness, Bray-Curtis, SIMPER and ANOSIM) were performed with the aid of the Primer ${ }^{\circledR}$ (Plymouth Routines in Multivariate Ecological Research) programme, 6.1.6 version. The two-way ANOVA was obtained with the STATISTICA ${ }^{\circledR}$ programme (7.0 version). 


\section{RESULTS}

A total of 1,477 specimens of 28 taxa were captured, belonging to the orders Amphipoda, Isopoda, Tanaidacea, Decapoda, Cumacea, and Mysidacea. Cumaceans were the most abundant group, accounting for $50 \%$ of the crustacean fauna, followed by amphipods (42\%). Isopods, brachyurans, and tanaidaceans each accounted for $1 \%$ of the community.

All taxa occurred in both strata, except mysids and brachyurans that occurred only in the aboveground stratum. Cumaceans and amphipods were more abundant in the belowground stratum, whereas isopods and tanaidaceans were more abundant in the aboveground stratum (Fig. 2). Amphipods of the family Megaluropidae and Photis sp. were only associated with the belowground. Brachyuran juveniles and adults were associated exclusively with the aboveground stratum, but the megalops were captured in the belowground stratum during the dry season (Tab. I).

The amphipods Hyale media Dana, 1853 and Ampithoe ramondi Audouin, 1828 were the most frequent taxa in the belowground stratum, whereas Microphoxus uroserratus Bustamante, 2002 was the most frequent taxa in the aboveground stratum.

Hyale media was dominant during the dry season in both the belowground (41.7\%) and aboveground (37\%) strata, whereas cumaceans dominated during the rainy season in these respective strata $(70.9 \%$ and $86.3 \%)$. In the belowground stratum, cumaceans were the densest taxon during both the dry (0.96 ind/g) and rainy $(6.27 \mathrm{ind} / \mathrm{g})$ seasons. In the aboveground stratum, cumaceans $(16.9 \mathrm{ind} / \mathrm{g}$ ) and $H$. media $(10.3 \mathrm{ind} / \mathrm{g})$ were the densest taxa in the dry season and cumaceans were the densest in the rainy season (59.9 ind/g). Among the community descriptors, despite of the variation found the seasonality significantly influenced only on the evenness (Fig. 3).

Although some species occurred in both strata, the similarity analysis indicated gradual changes in the crustacean fauna throughout the study occurring almost simultaneously

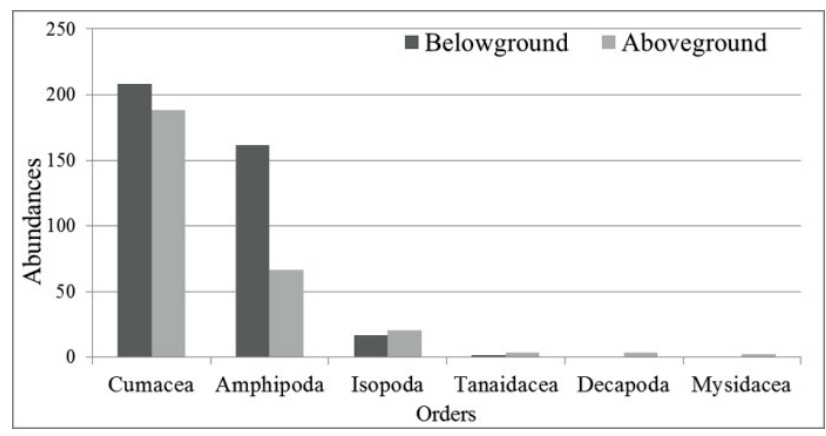

Fig. 2. Abundance of crustacean fauna captured in belowground and aboveground strata of Halodule wrightii meadow on Goiabeiras Beach, city of Fortaleza, state of Ceará, northeastern Brazil.

Tab. I. Frequency of occurrence and spatiotemporal distribution of crustacean fauna in Halodule wrightii meadow on Goiabeiras Beach, city of Fortaleza, state of Ceará, northeastern Brazil.

\begin{tabular}{|c|c|c|c|c|c|c|c|}
\hline \multirow{3}{*}{ Order } & \multirow{3}{*}{ Species } & \multicolumn{2}{|c|}{ Frequency of occurrence } & \multicolumn{4}{|c|}{ Spatiotemporal distribution } \\
\hline & & \multirow[t]{2}{*}{ Belowground } & \multirow[t]{2}{*}{ Aboveground } & \multicolumn{2}{|c|}{ Belowground } & \multicolumn{2}{|c|}{ Aboveground } \\
\hline & & & & Dry & Rainy & Dry & Rainy \\
\hline Mysidacea & & & Rare & & & $\mathrm{X}$ & $\mathrm{X}$ \\
\hline Cumacea & & Common & More Common & $\mathrm{X}$ & $\mathrm{X}$ & $\mathrm{X}$ & $\mathrm{X}$ \\
\hline \multirow[t]{8}{*}{ Decapoda } & Acantholobulus bermudensis Benedict \& Rathbun, 1891 & & Few Common & & & $\mathrm{X}$ & $\mathrm{X}$ \\
\hline & Acanthonyx dissimulatus Coelho, 1993 & & Rare & & & $\mathrm{X}$ & \\
\hline & Brachyuran megalopae & Few Common & & & $\mathrm{X}$ & & \\
\hline & Calappa angusta A. Milne-Edwards, 1880 & & Rare & & & $\mathrm{X}$ & \\
\hline & Callinectes ornatus Ordway, 1863 & & Few Common & & & $\mathrm{X}$ & \\
\hline & Epialtidae sp. & & Rare & & & $\mathrm{X}$ & \\
\hline & Pagurus sp. & & Rare & & & $\mathrm{X}$ & \\
\hline & Panopeidae spp. & & Common & & & $\mathrm{X}$ & $\mathrm{X}$ \\
\hline \multirow[t]{3}{*}{ Tanaidacea } & Chondrochelia dubia (Krøyer, 1842) & Few Common & Few Common & $\mathrm{X}$ & $\mathrm{X}$ & $\mathrm{X}$ & $\mathrm{X}$ \\
\hline & Paratanais sp. & & Rare & & & $\mathrm{X}$ & \\
\hline & Sinelobus stanfordi (Richardson, 1901) & Few Common & Few Common & $\mathrm{X}$ & & $\mathrm{X}$ & $\mathrm{X}$ \\
\hline \multirow[t]{5}{*}{ Isopoda } & Astacilla sp. & Few Common & Common & $\mathrm{X}$ & $\mathrm{X}$ & $\mathrm{X}$ & $\mathrm{X}$ \\
\hline & Erichsonella sp. 1 & Few Common & Rare & $\mathrm{X}$ & $\mathrm{X}$ & $\mathrm{X}$ & \\
\hline & Erichsonella sp. 2 & Few Common & Rare & & $\mathrm{X}$ & & $\mathrm{X}$ \\
\hline & Jaeropsis sp. & Common & Common & $\mathrm{X}$ & $X$ & $\mathrm{X}$ & $\mathrm{X}$ \\
\hline & Paracerceis sp. & Common & Common & $\mathrm{X}$ & $\mathrm{X}$ & $\mathrm{X}$ & $\mathrm{X}$ \\
\hline \multirow[t]{12}{*}{ Amphipoda } & Ampithoe ramondi Audouin, 1828 & More Common & Few Common & $\mathrm{X}$ & $\mathrm{X}$ & $\mathrm{X}$ & $\mathrm{X}$ \\
\hline & Caprella penantis Leach, 1814 & Few Common & Rare & $\mathrm{X}$ & $\mathrm{X}$ & $\mathrm{X}$ & \\
\hline & Cerapus sp. & Common & Few Common & $\mathrm{X}$ & $\mathrm{X}$ & $\mathrm{X}$ & $\mathrm{X}$ \\
\hline & Elasmopus rapax Costa, 1853 & Common & Few Common & $\mathrm{X}$ & $\mathrm{X}$ & $\mathrm{X}$ & $\mathrm{X}$ \\
\hline & Erichtonius brasiliensis Dana, 1853 & Common & Few Common & $\mathrm{X}$ & $\mathrm{X}$ & $\mathrm{X}$ & \\
\hline & Hyale media Dana, 1853 & More Common & Common & $\mathrm{X}$ & $\mathrm{X}$ & $\mathrm{X}$ & $\mathrm{X}$ \\
\hline & Lysianassidae sp. 1 & Few Common & Few Common & & $\mathrm{X}$ & $\mathrm{X}$ & $\mathrm{X}$ \\
\hline & Lysianassidae sp. 2 & Few Common & Few Common & $\mathrm{X}$ & $\mathrm{X}$ & $\mathrm{X}$ & \\
\hline & Megaluropidae sp. & Rare & & $\mathrm{X}$ & $\mathrm{X}$ & & \\
\hline & Microphoxus uroserratus Bustamante, 2002 & Common & More Common & $\mathrm{X}$ & $\mathrm{X}$ & $\mathrm{X}$ & $\mathrm{X}$ \\
\hline & Nototropis sp. & Common & Common & $\mathrm{X}$ & $\mathrm{X}$ & $\mathrm{X}$ & $\mathrm{X}$ \\
\hline & Photis sp. & Few Common & & $\mathrm{X}$ & $\mathrm{X}$ & & \\
\hline
\end{tabular}


in both strata, but primarily in the aboveground stratum, which also had a more clearly defined seasonal variation.

The similarity (46\%) of the community from the belowground stratum was mainly due to the abundance of $H$. media $(27.7 \%)$, cumaceans $(20.91 \%)$, and $A$. ramondi (11.2\%). Above $35 \%$ of similarity, these samples indicated two main groups (groups I and II) following seasonal sequences (Fig. 4). The dissimilarity between these groups and the other samples was of $76.9 \%$, also determined by cumaceans $(21.6 \%)$ and $H$. media $(21.3 \%)$.

Group I consisted of samples of the crustacean fauna captured between November 2006 and March 2007, with a similarity of $51 \%$, mainly due to the abundance of $H$. media (51\%). Group II comprised samples captured from April 2007 to July 2007 , with a similarity of $60 \%$, mainly due to the abundance of cumaceans (36\%). The dissimilarity between groups I and II was of $50.4 \%$, determined by the abundances of H. media (24.2\%), cumaceans (14.8\%), and Paracerceis sp. (10.5\%).

In the aboveground stratum, we also observed two main groups of samples (groups I and II) (Fig. 5), with a total similarity of $36.5 \%$, mainly due to the abundances of cumaceans $(52.7 \%)$. The similarity was of $48.4 \%$ in Group I, which comprised samples related to the rainy season (April to July 2006 and 2007) and October 2006. The abundance of cumaceans $(75.3 \%)$ was the main variable explaining the similarity of these samples. Group II comprised the samples from the dry season and the beginning of the rainy season (August 2006 to February 2007), with a total similarity of $40.4 \%$, mainly due to the abundance of $H$. media (46\%). The dissimilarity between these two groups of samples $(70.2 \%)$ was related to the abundance of cumaceans (29\%) and $H$. media $(20.7 \%)$.

The ANOSIM indicated a similar composition of the samples from the below and aboveground strata of the studied $H$. wrightii meadow, considering both the seasons and the two main sequences of samples (groups I and II of the two strata), with a similarity greater than $40 \%$ in both strata (Tab. II).

\section{DISCUSSION}

The majority of the taxa identified in the studied Halodule wrightii meadow occurred both in belowground and aboveground strata, which did not allow us to clearly discriminate the groups of species that belonged to the infauna or epifauna, as also observed for the molluscs associated (BARRos \& RochA-BARREIRA, 2013). Moreover, expected significant differences were also not found among different habitats or species of seagrass (YOKEL, 1975; LEWIS, 1984; HeCK JR et al., 1989; EdGAR, 1990; CORBISIER, 1994; GARCIA et al., 1996; JERNAKOFF \& NiELSEN, 1998; NAKAOKA et al., 2001; Rosa \& BeMvenuti, 2007). a)
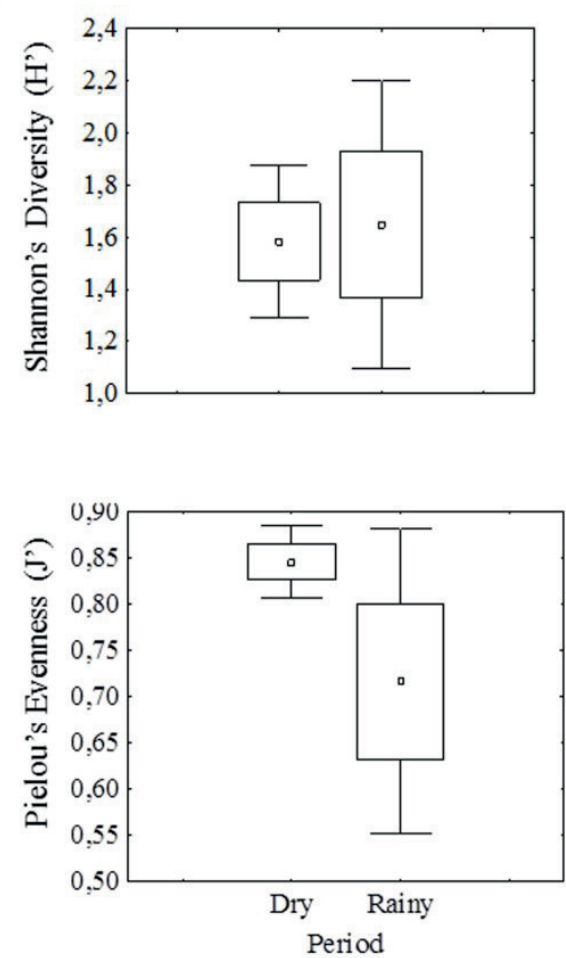

b)
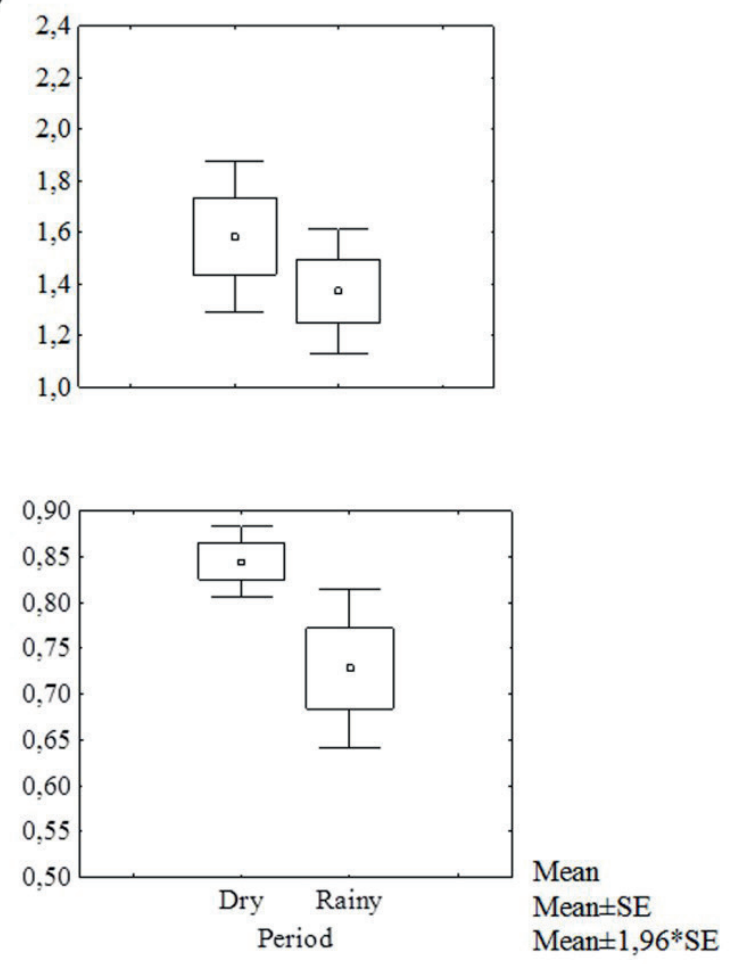

Fig. 3. Mean Shannon diversity and Pielou evenness indices of crustacean fauna associated with belowground and aboveground strata of Halodule wrightii meadow in dry and rainy seasons on Goiabeiras Beach, city of Fortaleza, state of Ceará, northeastern Brazil (a, indices for community associated with belowground stratum; $b$, indices for community associated with aboveground stratum). 


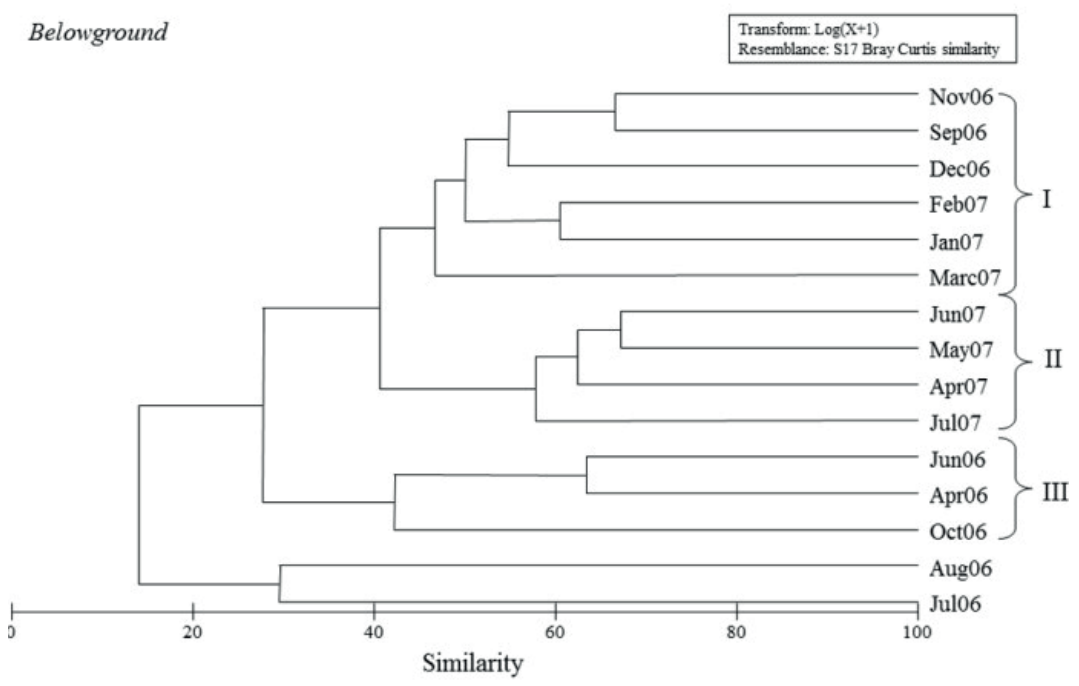

Fig. 4. Similarity among samples from belowground stratum of Halodule wrightii meadow on Goiabeiras Beach, city of Fortaleza, state of Ceará, northeastern Brazil; Legend: I) samples collected in predominantly dry months; II) samples collected in predominantly rainy months; III) samples collected in both climatic periods.

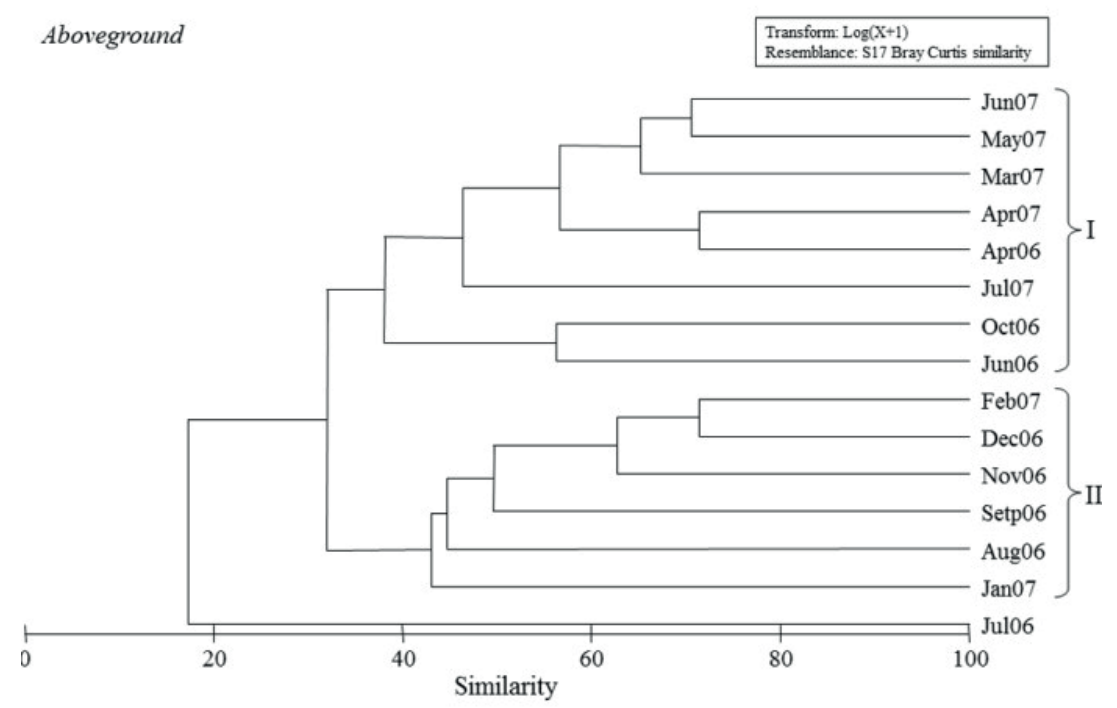

Fig. 5. Similarity among samples from aboveground stratum of Halodule wrightii meadow on Goiabeiras Beach, city of Fortaleza, state of Ceará, northeastern Brazil; Legend: I) samples collected in predominantly dry months; II) samples collected in predominantly rainy months.

The lack of significant differences between infauna and epifauna may be also related to the complexity of these ecosystems (Heck JR et al., 1989; JeRNAKOFF \& Nielsen, 1998) and the interference of other external environmental variables (EDGAR, 1990; JeRnAKoff \& NiELSEN, 1998; NAKAOKA et al., 2001), making the role of seagrasses secondary on the community structure (HARRIAGE et al., 2006). Furthermore, in general the benthic macrofauna exhibit variations in vertical distribution related to seasonal changes in the water and sediment (JoRCIN, 1999).

The high frequency of cumaceans and Microphoxus urosserratus in the aboveground stratum is probably associated with their feeding habits, as also pointed out by
Tab. II. Results of one-way ANOSIM for samples collected in dry and rainy seasons and groups with similar abundance values in Halodule wrightii meadow on Goiabeiras Beach, city of Fortaleza, state of Ceará, northeastern Brazil.

\begin{tabular}{lccc}
\hline Stratum & Factors & R value & $\mathrm{p} \mathrm{value}$ \\
\hline Belowground & Dry x Rainy seasons & 0.001 & 0.410 \\
& I x II groups & -0.008 & 0.467 \\
Aboveground & Dry x Rainy seasons & 0.058 & 0.272 \\
& I x II groups & 0.109 & 0.137 \\
\hline
\end{tabular}

other researchers for crustaceans and molluscs (JERNAKOFF \& Nielsen, 1998; NaKaOKa et al., 2001). Both taxa leave buried or semi-buried and often feed on the sediment surface 
(MacDonald et al., 2010). The feeding habit could also explain the increased densities of cumaceans in both strata during the rainy season, when occurs an increase of organic matter in the sediment (BARROS \& ROCHA-BARREIRA, 2013), and probably in the water column. Unfortunatelly, we could not identify them to specific level. It would define key-species of the group in this ecosystem, which could help in future monitoring activities of this meadow.

After cumaceans, the amphipod H. media was an important taxon in terms of density and dominance, as in other seagrass meadows (JeRNAKOFF \& NiELSEN, 1998). This amphipod lives basically on the surface of the sediment and phytal ecosystems of the intertidal region. Regarding its feeding habits, $H$. media is essentially a scraper and grazer of microorganisms of macroalgae and microalgae (TARARAM et al., 1985; 1986; MACDonald et al., 2010). Amphipods may have risen from surrounding macroalgae banks and deposited in the meadow by waves in the dry season or may have been attracted by the availability of epiphytes (Hypnea musciformis Lamourox), as the biomass of which increases in this period (BARROS \& ROCHA-BARREIRA, 2013, 2014). Species richness may increase when other types of habitats are present (BOLOGNA \& HeCK JR, 1999; GILlandERs, 2006), although this pattern depends on the type of seagrass substrate (JERNAKOFF \& NiELSEN, 1998).

In addition to the probable epiphytic contribution, wave action also favoured the input of specimens surrounding the ecosystem, leading to an increase in the average diversity index during the dry season. This was the case of brachyuran juveniles and adults as well as some species of tanaidaceans, isopods, and amphipods, which only occurred in the aboveground stratum during the dry season, as previously reported for some mollusc species (BArros \& Rocha-Barreira, 2013). The patchiness of the meadow (BARROS \& Rocha-BARREIRA, 2014) probably contributed to the occurrence of these organisms due to the edge effect, where there is a greater concentration of nutrients and organic matter (EGGLESTON et al., 1999; BolOGNA \& HeCK JR, 2002; MACREADIE et al., 2010). This factor may have contributed to the significant increase in evenness indices in the dry season.

The influence of seasonality on crustacean abundance demonstrated in the similarity analysis, with some interannual differences between corresponding samples from the different studied years, especially considering the rainy seasons, was also observed by HARRIAGE et al. (2006) for the macrofauna associated with Posidonia oceanica (Lipkin) in Prelo Bay, Italy. However, these authors considered that physical factors play a secondary role in the structure of the benthic macrofauna, contrary to what was observed in the present study and in a study of NAKAOKA et al. (2001), who investigated benthic macrofauna associated with Zostera marina Linnaeus and Zostera caulescens Miki in Otsuchi Bay, Japan. However, this factor is directly associated with the characteristics of the studied site.

The similarity dendrogram revealed slow changes in the community along the study in response to environmental changes. The community from belowground was more stable, as suggested by other authors (GAMBI et al., 1995; JERNAKOFF \& NiELSEN, 1998), probably because the leaves changed their arrangement primarily in relation to the belowground stratum (BARros \& Rocha-BARreIra, 2014). In addition to the seagrass structure, the temporal dynamics of the leaves may exert a significant influence on the epifauna (JERNAKOFF \& NIELSEN, 1998). Furthermore, the aboveground fauna seems to be more strongly affected by environmental actions (BARROS \& RochA-BARREIRA, 2013). EdGAR (1990) also found a significant seasonal difference in the captured fauna associated with seagrass leaves. The lowest seasonal fluctuations are found for the rhizomes and roots (BARROS \& ROCHA-BARREIRA, 2014) and for the fauna associated with the belowground stratum (GAMBI et al., 1995), since this stratum is a less stressful and more stable environment than the aboveground stratum.

Thus, the crustacean community exhibited gradual changes along the study, in both the belowground and aboveground strata, but the seagrass structure was not sufficient to explain the vertical distribution of the crustacean fauna along the time. The taxa were also influenced by external processes associated with the effects promoted by the seasonality on the ecosystem as a whole (i.e. the patched meadow and the edge effect, as well as the action of waves and the input of organic matter in the meadow), which have an important role in the productivity of this meadow.

Acknowledgments. The authors would like to thank Dr. Petrônio Alves Coelho (in memoriam) for his assistance at the Laboratório de Carcinologia da Universidade Federal de Pernambuco (Brazil). The first author is also grateful to the Conselho Nacional de Desenvolvimento Científico e Tecnológico (CNPq) for awarding a Master's scholarship at the time of the study.

\section{REFERENCES}

Abele, L. G. 1974. Species diversity of decapods crustaceans in marine habitats. Ecology 55:56-61.

Alves, M. S. \& Araújo, M. J. G. 1999. Moluscos associados ao fital Halodule wrightii Ascherson na ilha de Itamaracá-PE. Trabalhos Oceanográficos 27(1):91-99.

Barros, K. V. S.; Jardim, J. \& Rocha-Barreira, C. A. 2013. Ecological observations on Polyplacophora in a Halodule wrightii Ascherson meadow and new records for Northeast and Brazilian coast. Revista Nordestina de Zoologia 7(1):27-40.

Barros, K. V. S. \& Rocha-Barreira, C. A. 2009/2010. Caracterização da dinâmica espaço-temporal da macrofauna bentônica em um banco de Halodule wrightii Ascherson (Cymodoceaceae) por meio de estratificação. Revista Nordestina de Zoologia 4(1):73-81.

Barros, K. V. S. \& Rocha-Barreira, C. A. 2013. Responses of the molluscan fauna to environmental variations in a Halodule wrightii Ascherson ecosystem from Northeastern Brazil. Annals of the Brazilian Academy of Sciences 85(4): 1397-1410.

Barros, K. V. S. \& Rocha-Barreira, C. A. 2014. Influence of environmental factors on a Halodule wrightii Ascherson meadow in Northeastern Brazil. Brazilian Journal of Aquatic Science and Technology 18(2):31-41.

BJÖRK, M.; SHORT, F.; MClEOD, E. \& BEER, S. 2008. Managing seagrasses for resilience to climate change. Gland, World Conservation Union Global Marine Programme. 55p.

Bologna, P. A. X. \& Heck JR., K. L. 1999. Macrofaunal associations with seagrass epiphytes: Relative importance of trophic and structural characteristics. Journal of Experimental Marine Biology and Ecology 242:21-39. 
Bologna, P. A. X. \& Heck JR., K. L. 2002. Impact of habitat edges on density and secondary production of seagrass-associated fauna. Estuaries 25(5):1033-1044.

Bone, D. \& SAN MARTín, G. 2003. Ecological aspects of syllids (Annelida: Polychaeta: Syllidae) on Thalassia testudinum beds in Venezuela. Hydrobiologia 496:289-298.

Burdick, D. M. \& KENDRICK, G. A. 2001.Standards for seagrass collection, identification and sample design. In: SHORT, F. T. \& Coles, R. G. eds. Global seagrass research methods. Amsterdam, Elsevier, p. 79-100.

Corbisier, T. N. 1994. Macrozoobentos da Praia do Codó (Ubatuba, SP) e a presença de Halodule wrightii Ascherson. Boletim do Instituto Oceanográfico 42:99-111.

Costa, A. C. \& Ávila, S. P. 2001. Macrobenthic mollusc fauna inhabiting Halopteris spp. Subtidal fronds in São Miguel Island, Azores. Scientia Marina 65(2):117-126.

Creed, J. C. \& Kinupp, M. 2011. Small scale change in mollusk diversity along a depth gradient in a seagrass bed off Cabo Frio (Southeast Brazil). Brazilian Journal of Oceanography 59(3):267-276.

Da Rocha, C. M. C.; Venekey, V.; bezerra, T. N. C. \& Souza, J. R. B. 2006. Phytal marine nematode assemblages and their relation with the macrophytes structural complexity in a Brazilian tropical rocky beach. Hydrobiologia 553:219-230.

D'InCAO, F. 1982. Distribuição e abundância de Penaeus (Farfantepenaeus) paulensis Pérez-Farfante, 1967, em relação aos parâmetros ambientais na Lagoa dos Patos, RS, Brasil. Atlântica 5(2):3-7.

DuARte, C. M. \& Kirkman, H. 2001.Methods for the measurement of seagrass abundance and depth distribution. In: SHORT, F.T. \& Coles, R.G. eds. Global seagrass research methods. Amsterdam, Elsevier, p. 141-154.

EDGAR, G. J. 1990. Population regulation, population dynamics and competition amongst mobile epifauna associated with seagrass. Journal of Experimental Marine Biology and Ecology 144:205-234.

Eggleston, D. B.; Elis, W. E.; Etherington L. L.; Dahlgren, P. \& Posey, M. H. 1999. Organism responses to habitat fragmentation and diversity: Habitat colonization by estuarine macrofauna. Journal of Experimental Marine Biology and Ecology 236:107-132

Gambi, M. C.; Giangrande, M. A.; Martinelli, M. \& Chessa, L. A. 1995. Polychaetes of a Posidonia oceanica bed off Sardinia (Italy): Spatiotemporal distribution and feeding guild analysis. Scientia Marina 59:129-141.

Garcia, A. M.; Vieira, J. P.; Bemvenuti, C. E. \& Geraldi, R. M. 1996. Abundância e diversidade de crustáceos decápodos dentro e fora de uma pradaria de Ruppia maritima L. no estuário da Lagoa dos Patos (RS - Brasil). Nauplius 4:13-128.

Harriage, A. C.; Bianchi, C. N. \& Albertelli, G. 2006. Soft-bottom macrobenthic community composition and biomass in a Posidonia oceanica meadow in the Ligurian Sea (NW Mediterranean). Estuarine, Coastal and Shelf Science 70:251-258.

Heck JR., K. L.; Able, K. W.; Fahay, M. P. \& Roman, C. T. 1989. Fishes and decapod crustaceans of Cape Cod eelgrass meadows: species composition, seasonal abundance patterns and comparison with unvegetated substrates. Estuaries 12(2):59-65.

Hemminga, M. A. \& Duarte, C. M. 2000. Seagrass ecology. Cambridge, Cambridge University Press. 298p.

JeRnAKOFF, P. \& NiELSEN, J. 1998. Plant-animal associations in two species of seagrasses in Western Australia. Aquatic Botany 60:359-376.

JoRCIN, A. 1999. Distribuição do macrozoobentos na coluna vertical dos sedimentos da região estuarina de Cananéia (SP), Brasil. Brazilian Journal of Oceanography 47(1):79-85.
KIKUCHI, T. 1974. Japanese contributions on consumer ecology in eelgrass (Zostera marina L.) beds, with special reference to trophic relationships and resources in inshore fisheries. Aquaculture 4:145-160.

KöPpEN, W. 1948. Climatologia: un estudo de los climas de la tierra. Ciudad del Mexico, Fondo de Cultura Econômica. 479p.

LEWIS, F. G. 1984. Distribution of macrobenthic crustaceans associated with Thalassia, Halodule and bare sand substrata. Marine Ecology Progress Series 19:101-113.

MacDonald, T. A.; Burd, B. J.; Macdonald, V. I. \& van RoodselaAr, A. 2010. Taxonomic and feeding guild classification for the marine benthic macroinvertebrates of the Strait of Georgia, British Columbia. Canadian Technical Reports of Fisheries and Aquatic Sciences 2874:1-63.

Macreadie, P. I.; Connolly, R. M.; Jenkins, G. P.; Hindell, J. S. \& KeOugh, M. J. 2010. Edge patterns in aquatic invertebrates explained by predictive models. Marine and Freshwater Research 61:214-218.

Morais, J. O.; Freire, G. S. S.; Pinheiro, L. S.; Souza, M. J. N.; Carvalho, A. M.; Pessoa, P. R. S. \& Oliveira, S. H. M. 2006. Ceará. In: Muehe, D. org. Erosão e Progradação do Litoral Brasileiro. Rio de Janeiro, Ministério do Meio Ambiente, p. 132-154.

NAKAOKA, M. 2005. Plant-animal interactions in seagrass beds: ongoing and future challenges for understanding population and community dynamics. Population Ecology 47(3):167-177.

Nakaoka, M.; Toyohara, T. \& Matsumasa, M. 2001. Seasonal and between-substrate variation community in a multiespecific seagrass bed of Otsuchi Bay, Japan. Marine Ecology 22(4):379-395.

Omena, E. \& CReEd, J. C. 2004. Polychaete fauna on seagrass beds (Halodule wrightii Ascherson) along the coast of Rio de Janeiro (Southeast Brazil). Marine Ecology 25(4):273-288.

Orth, R. J.; Heck, K. L. \& MontFrans, J. 1984. Faunal communities in seagrass beds: A review of influence of plant structure and prey characteristics on predator-prey relationships. Estuaries 7(4):339-350.

Phillips, R. C. \& Meñez, E. G. 1988. Seagrasses. Smithsonian Contribution to the Marine Science. Washington, Smithsonian Institution Press. 104p.

Rosa, L. C. \& Bemvenuti, C. E. 2007. Seria a macrofauna bentônica de fundos não consolidados influenciada pelo aumento na complexidade estrutural do habitat? O caso do estuário da Lagoa dos Patos. Brazilian Journal of Aquatic Science and Technology 11(1):51-56.

Tararam, A. S.; Y. Wakabara, Y. \& Mesquita, H. S. L. 1985. Feeding habits of Hyale media (Dana, 1853) (Crustacea - Amphipoda). Boletim do Instituto Oceanográfico de São Paulo 33(2):193-199.

Tararam, A. S.; Wakabara, Y. \& Leite, F. P. P. 1986. Vertical distribution of amphipod living on algae of a Brazilian intertidal rocky shore. Crustaceana 51(2):183-187.

Toyohara, T.; NAKaOKa, M. \& AioI, K. 1999. Population Dynamics and Reproductive Traits of Phytal Gastropods in Seagrass Bed in Otsuchi Bay, North-Eastern Japan. Marine Ecology 20(3-4):273-289.

Williams, S. L. \& Heck, K. L. 2001. Seagrass community ecology. In: Bertness, S. D. G. \& Hay, M. E. eds. Marine Community Ecology. Sunderland, Sinauer, p. 317-338.

YOKEL, B. J. 1975. Estuarine biology, rookery bay land use studies: environmental planning strategies for the development of a mangrove shoreline. Washington, The Conservation Foundation. 112p.

ZiEMAN, J. C. \& ZiEMAN, R. T. 1989. The ecology of the seagrass meadows of the west coast of Florida: a community profile. Washington, U.S. Department of the Interior Fish and Wildlife Service Research and Development. Biological Report 85(7.25). 155p. 